\title{
An Overview of Rainwater Harvesting for Sustainable Future in Malaysia
}

\author{
Shazwan Mohamed Shaari \\ Department of Quantity Surveying, Faculty of Built Environment, \\ Universiti Malaysia Sarawak, Kota Samarahan, Sarawak, Malaysia \\ msshazwan@unimas.com \\ Tel: $+6012-4723678$
}

\begin{abstract}
This paper looks into the types of Rainwater Harvesting System (RWH), system, benefits, water governance and community awareness and level of acceptance of RWH implementation for future sustainability. RWH is not new in Malaysia, successful studies and existing projects can be as indicators for Malaysia to move further. This paper will discuss the benefits of RWH, types of system, water governance and level of public acceptance. A case study of RWH project in Sarawak will be discussed too as part of author contribution in these fields of research.
\end{abstract}

Keywords: Rainwater harvesting system, sustainable future, case study, knowledge transfer

eISSN: 2398-4287@ 2020. The Authors. Published for AMER ABRA cE-Bs by e-International Publishing House, Ltd., UK. This is an open access article under the CC BYNC-ND license (http://creativecommons.org/licenses/by-nc-nd/4.01. Peer-review under responsibility of AMER (Association of Malaysian Environment-Behaviour Researchers), ABRA (Association of Behavioural Researchers on Asians) and cE-Bs (Centre for Environment-Behaviour Studies), Faculty of Architecture, Planning \& Surveying, Universiti Teknologi MARA, Malaysia.

DOI: https://doi.org/10.21834/ebpj.v5i14.2232

\subsection{Introduction}

Malaysia is blessed with high annual rainfall with an average of 250 centimetres (98 in) a year, and the average temperature is $27^{\circ} \mathrm{C}$ $\left(80.6^{\circ} \mathrm{F}\right)$. These have led to frequent rain and increased water capacity at rivers and dams around the country. The collected water was a beneficial source for domestic and industrial users all over the country. A systematic treated water process is used for residential such as toilet flushing, washing clothes or vehicles and garden watering. In an industrial and commercial area, the water is the primary source for construction works, food process and productions, manufactures and agriculture. However, according to Md Lani et al., (2018), increasing water had made existing water supply infrastructure strained and some is getting polluted due to the urbanization process nowadays. Despite the abundant rain, drought season that recently faced by the country has disrupted and shortage of domestic water supply too. These phenomena also caused by scorching climate and global climate change issues. The future rainfall in several states in Malaysia is predicted to decrease due to climate change (Law and Bustami, 2013). In Malaysia, the spatial analysis study showed that most of the areas are more prone to a short term of drought and higher severity, especially at the north part of the Central Region and Southern Region and central part of the East Coast (Fung et al., 2020).

Based on the above unpredictable microclimatic scenarios, there is a severe need for Malaysians have proper water storage such as Rainwater Harvesting (RWH) for their primary usage. RWH can be defined as a direct collection of rainwater from roofs and other purpose-built catchments for domestic, industrial and agriculture use. It is a system to recycle and reuse the runoff to meet demand using storage volume, roof area, irrigated area and indoor non-potable as inputs. Research has shown that by continuously reuse the rainwater, environment and ecosystem could be sustained (Belmeziti et al.,2014; Lee et al., 2016) and their previous research is aligned with today's Sustainable Development Goal (SDG 6). SDG 6 has addressed the importance to conserve and sustainably managed the water resources.

Furthermore, United Nation Human Development (2020) has declared that water is at the core of sustainable and is critical for the socio-economic, ecosystem, the survival of the nation, thus making it beneficial for the human civilization. In Malaysia, RWH has high 
acceptance. A case study of RWH project in Sarawak will be discussed too as part of author contribution in these field of research potential to be promoted as an alternative for water supply due to dynamic climate and continued support from the government. Besides, water resources can prioritize by making it everybody's business and emphasize the link between communities and water to ensure that the resource is of better value. This paper will discuss the benefits of $\mathrm{RWH}$, types of system, water governance and level of public

\subsection{Rainwater Harvesting System}

Whether it is large or small, a rainwater harvesting (RWH) system has five essential components, according to the Department of Irrigation and Drainage (2009). There are two types of RWH system, such as the conventional system and the integrated/innovative system. The conventional system contains the Catchment area (the surface area which catches the rainfall. It may be a roof or impervious pavement/landscaped areas), secondly the Conveyance (channels/pipes that transport the water from the catchment area to storage), thirdly the First flush (the systems that filter and remove contaminants and debris using separation devices), fourthly the Storage tanks (Where collected rainwater is stored) and the Distribution (the system that delivers the rainwater to the point of use, either by gravity or pump). Figure 1 shows the components of a Conventional Rainwater Harvesting (RWH) System. The integrated/innovative RWH system is ongoing globally by used by the interrelated modular system and collapsible tank (Halim et al., 2018). A dual storage facilities were incorporated into the RWH system, namely retention, storage (to meet user demand) and detention storage (serves as a temporary holding space for runoff control). A more sophisticated system can be designed with multiple benefits by combining the RWH system with other facilities (rain garden, bio-retention cell) (Campisano et al., 2017). The most advanced systems is by using the smart apps, software and programming and sensor. It can improve the system facilities and set an optimal management service for users. Figure 2 shows the example of integrated/innovative RWH system.

\subsection{Benefits of Rainwater Harvesting System (RWH)}

An international colloquium on Water Research 2020 has reported a successful project by NAHRIM on rainwater as drinking water with several water catchment areas and incubators to process the rainwater (Mohamad, 2020). According to Law and Bustami (2013), Belmeziti et al., (2014) and Md Lani (2018), rainwater harvesting (RWH) is the best solution and alternative water supply too. By having systematic RWH, it can minimize water scarcity consequences and value for socio-economic (Md Lani, 2018), delay the surface water runoff which is very useful to prevent the occurrence of flash flood and erosion (Hasim et al., 2020), prolong the water storage during dry periods (Kuok and Chiu, 2020) improve household water management in the rural area (Nasif and Roslan, 2016), and for landscaping and agricultural purposes (Lee at al., 2016). In Malaysia, it was observed that RWH installation in the building has helped in water saving. For example, in Kuching, RWH has satisfied about 34\%-44\% of total monthly household water usage for a single storey house (Kuok and Chiu, 2020). An experiment in a residential area at Tanjung Malim reported that the house owner has managed to save about $40 \%$ of treated water usage when implementing the RWH system (Che Ngah et al., 2014). Research done at Bandar Sri Iskandar, Perak identified that large roof area and storage tank could save more water for recycling use (Nasif and Roslan, 2016). One of the public schools in Malacca has used the RWH as an alternative water supply for the school garden, and it could reduce $50 \%$ of the rainwater flow rate into the drainage system and utility bills as well (Halim et al., 2018). In Shah Alam, Sungai Buloh and Putrajaya residential area, RWH approach has saved $40 \%$ of water consumption monthly (Saidin, 2009).

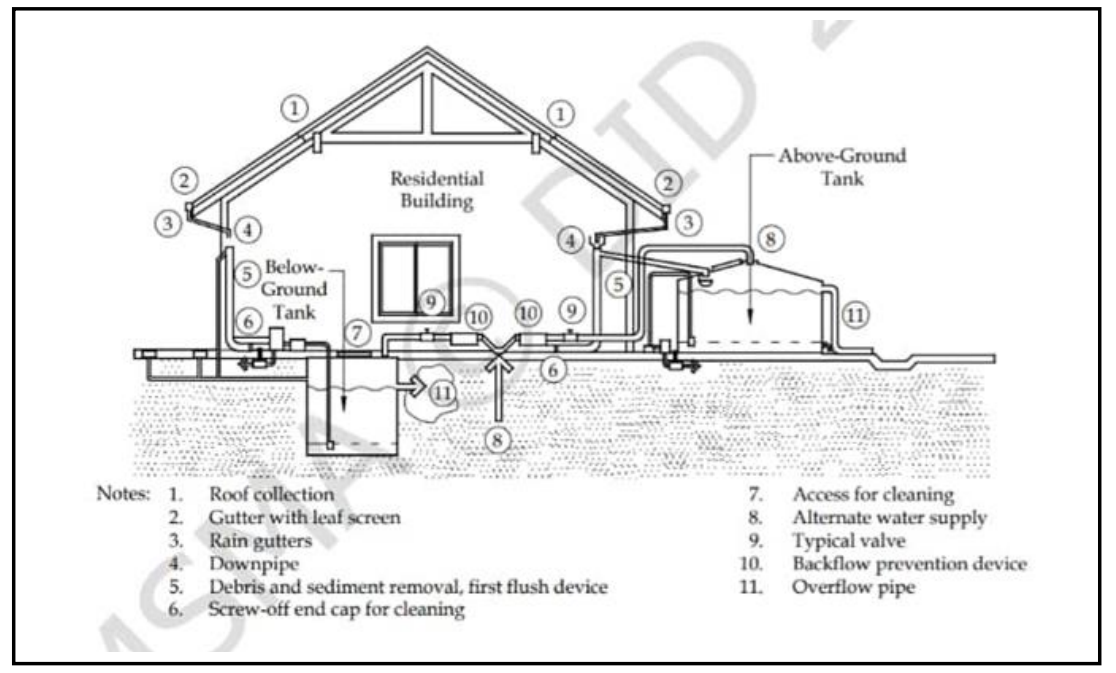

Fig. 1: Components of Conventional Rainwater Harvesting (RWH) System Department of Irrigation and Drainage, 2009 


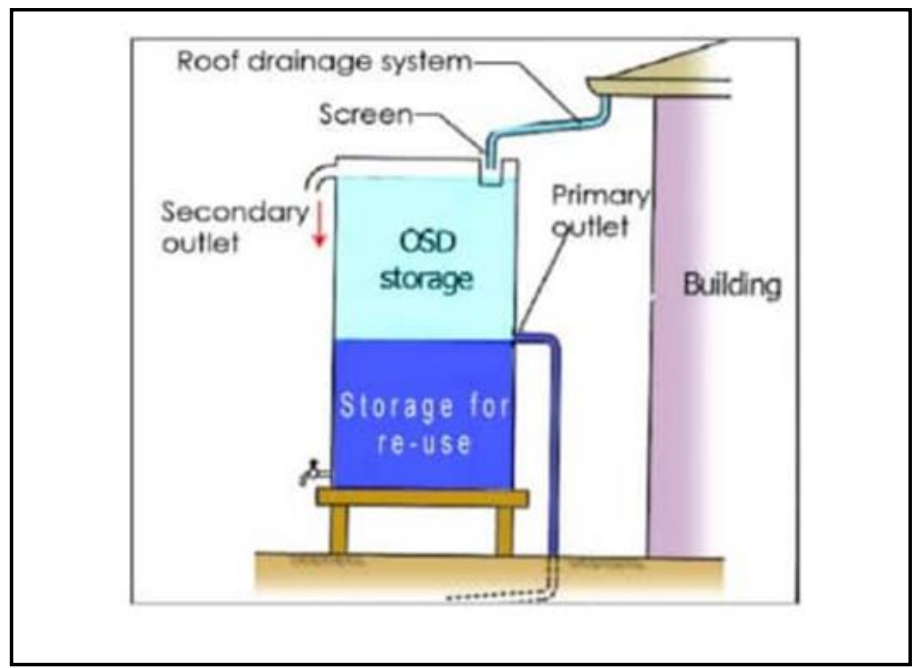

Fig. 2: Multipurpose Tank to Discharge Excessive Water into Strormwater Drainage System/ Raingarden Cell and for Domestic Use Department of Irrigation and Drainage, 2009

\subsection{Water Governance in Malaysia}

According to Jimenez et al., (2020), in the international arena, water governance has emerged as a vital factor to adequate and sustained progress towards achieving Sustainable Development Goal (SDG) 6. Currently, Malaysia faces dynamic and fast-changing in terms of political, legal and economic aspects, therefore, it is crucial to ensure the water resources are carefully managed and governed. Good governance water practice in Malaysia will promote the involvement of various stakeholder, practitioners and increase the public interest. Following are the policies and guidelines to manage the water resources (Table 1- Table 2).

Table 1. Policies and Guidelines for Rainwater Harvesting by Malaysia Government

\section{Guidelines}

Guidelines for installing a Rainwater Collection and Utilization

System

RWHS: Guidebook for Planning and Design

Guideline on Eco-Efficiency in Water Infrastructure for Public

Buildings in Malaysia

Urban Stormwater Management Manual for

Malaysia, MSMA 2nd Edition

Panduan Pelaksanaan Inisiatif Pembangunan Kejiranan

Hijau-Sistem Pengumpulan dan Penggunaan Semula Air

Hujan

Garis Panduan Perancangan Kejiranan Hijau

Garis Panduan Sistem Pengumpulan dan

Penggunaan Air Hujan

Urban Stormwater Management-Part 6: RWHS, MS2526-

6:2014

$\begin{array}{lc}\text { Ministry of Housing and Local Government } & \begin{array}{c}\text { Year } \\ 1999\end{array} \\ \begin{array}{lc}\text { Department of Irrigation and Drainage Malaysia } \\ \text { National Hydraulic Research Institute of Malaysia }\end{array} & 2009 \\ \text { Department of Irrigation and Drainage Malaysia } & 2011 \\ \text { Federal Town and Country Planning Department } & 2012 \\ \text { Federal Town and Country Planning Department } & 2012 \\ \text { Federal Town and Country Planning Department } & \\ \text { Department of Standards Malaysia } & 2012\end{array}$

Implementation of Rainwater Harvesting in Malaysia

(http://www.eng.warwick.ac.uk)

Table 2. Government Act and Strategic Plan Related to Sustainable Water Management

Act/ Strategic Plan

NAHRIM Strategic Plan (2016-2020)

National Policy on Climate Change 2009

National Policy on the Environment 2002

11th Malaysia Plan (2016-2020)
Statement

Strategic Plan 1:

Innovative research on water resource and water security for sustainable natural resources that aligned with National Water Policy 2012 and National Policy on Climate Change 2009.

Principles 2:

Strengthen the implementation of climate change actions that contribute to environmental conservation and sustainable use of water resources.

Key Action 1:

Conduct systematic reviews and harmonized existing legislation, policies and plans on water resources.

Principle 4:

Manage natural resource utilization, sustain the resource base and prevent degradation of the environment.

Focus Area B: Sustainable consumption and production

A concept that promotes economic growth without compromising the

environment through efficient use of water. 

Integrated Water Resource Management of Malaysia
(IWRM)

National Landscape Policy 2011
10 Pillars for IWRM: Water for All

1- harmonizing water governance, 2-ensuring sustainable water resources, 3mainstreaming water in national agendas, 4-innovative infrastructure design, 5 safe and affordable water services, 6 - increase water ownership and participation, 7-transparent data-driven decision making, 8-creating business opportunities for water players, 9-strengthening disaster risk governance, 10 strengthening scientific community

Mission 2:

To ensure a natural landscape resources are optimally utilized by considering protection, conservation and preservation of sustainable management systems for the use of heritage and tourism.

Author, 2020

\subsection{Community Awareness and Level of Acceptance}

Studies have identified several factors influenced social acceptance on RWH such as water quality (Che Ani, 2009), financial viability (Lee at al., 2016; Shaari et al., 2009; Md Lani et al., 2018), expertise (Che Ani, 2009; Md Lani et al., 2018; Mohamad, 2020) and community awareness (Hasim et al., 2020; Lee et al., 2016). Research done by Mohamad et al. (2014) reported that 75\% of housing developers in Malaysia aware of RWH system, and $64 \%$ of them agreed that RWH is part of a strategy to achieve sustainable development. Despite having a high percentage of awareness, however, more than $80 \%$ of developers had no experience in RWH installation in their residential project. A lot of commitments are needed for experts to gain knowledge and practice the RWH in their project. Survey findings among 16 managerial position in 4 universities in Malaysia identified that water-saving falls under third priority after the energy and waste efficiency in an existing building. Other than that it is predicted that users are aware of having clean water, but less preferred to spend much time and effort to hire for the contractors or build their system. It is also aligned with research done by Kuok and Chiu (2020), Zakaria (2019) and NAHRIM Research Centre (2020) that in order to encourage public participation in rainwater harvesting practice, government agencies and the mass media should promote the benefits and importance of rainwater harvesting and utilization through campaigns or by social media The Malaysian Green Building Index was launched on 21st May 2009, and it is recognized as a green rating tool to promote sustainable development practices and awareness among industrial player in building construction. Domestic water conservation practice or water saving in the buildings given a rating of $12 \%$ in the index criteria. Thus, it provides a potential room for designers and contractors to implement and improve the RWH system by look into detail on building design and technical aspect in their projects. RWH is moving forward as many urban and rural projects have received sponsors, grant, consultation and community service. By having this, public participation and opportunity for knowledge transfer can be increased.

\subsection{Case Study: Rainwater Harvesting at Kampung Sungai Putin, Asajaya, Sarawak}

\subsection{Project Background}

A rainwater harvesting project will be carry out at Kampung Sungai Putin, Asajaya, Sarawak. Kampung Sungai Putin is facing water shortages due to low water pressure every day. A rainwater harvesting project was planned to be proposed at the mosque of Kampung Sungai Putin. By taking the potential of mosque as a public gathering place, community participation, and knowledge transfer among the villagers will be conducted during the project implementation. This approach will encourage the villagers to learn and practice the rainwater installation at their house. It is hoped that the study outcomes will be useful for further research and reference to solve the water problem in the Sarawak rural areas. The objectives of this project is 1) to identify the site problem and potential of rainwater harvesting to be developed, 2) to collaborate with the local community to construct a proper rainwater harvesting system and 3) to measure level of public awareness, the effectiveness of knowledge transfer and, technical and financial feasibility.

\subsection{Research Methodology}

This project required two phases of the study. The first phase is on Site Observation and Interview Session. The second phase is on Project Implementation and Questionnaire Survey. The first phase has been completed, and the findings will be discussed in this paper while the second phase is still under progress and had to be stopped temporarily due to the COVID-19 pandemic. During site observation, several data have been collected in related to site background, microclimatic information, and building design. A semistructured interview has been conducted among the villagers to get their opinion and share their experience. Information gathered from phase one were studied, and there is a high demand for the villagers to have a proper rainwater harvesting system. After the system has been constructed, a questionnaire survey will be conducted on-site to determine the effectiveness of the RWH system. Followings are the findings from phase one of the study.

\subsubsection{Site Details}

The project site is located at Kampung Sungai Putin, Asajaya, $63 \mathrm{~km}$ from Kuching, Sarawak. The latitude and departure of Kampung Sungai Putin are $1^{\circ} 31^{\prime} 55.0^{\prime \prime} \mathrm{N} 110^{\circ} 39^{\prime} 52.5^{\prime \prime} \mathrm{E}$ respectively. The villagers received their water supply from the pipe system built by the state government. However, due to low water pressure and poor maintenance of pipe connection, every household in Kampung Sungai Putin face a clean water shortage for their daily needs. According to one of the villagers, during the raining season, they will collect the rainwater by capturing it into their water tanks and controlling the water usage available. However, during the dry season, it is becoming more challenging for them to gather the water resource from the rain. For the record, the majority of the houses receive at least one unit 
of the medium cylindrical water tank (2000 gallon), and there are about 50-60 water tanks supplied by the Sarawak government around the village. However, less than $30 \%$ were fully utilized and applied the right construction technique of the rainwater harvesting system. Insufficient filtering system and improper installation method have caused water contaminated, and some of the tanks are unable to capture the water. Interview and site observation conducted by the author has confirmed this.

\subsubsection{Microclimatic Information}

It is known that Sarawak is located on the Borneo Island were its highly influenced by their landform locations which are surrounded by the sea and many rivers and this will give effect to rainfall, temperature and wind pattern of the area. From the study, Asajaya has an immense value of rainfall intensity in 2019 which is 18, and it is predicted that Kampung Sungai Putin will receive an extra 20\%-40\% of rainfall from July 2020 until October 2020 and less 20\%-40\% of rainfall from November 2020 until December 2020 (Malaysian Meteorological Department, 2020). Based on this information, it can be concluded that from July until October is an appropriate time for the villages to preserve the rainwater water and carry on their farming and aquaculture business activities. However, during dry season, they need to reduce the outdoor watering activities and to make sure that there are no pipe leakages around the village. The climate change issue also has influenced the rainfall pattern and drought season at the site project. As mentioned by the villagers, sometimes the drought season takes more than two weeks, and they have no left preserved water to be used.

\subsubsection{Building Design}

According to a site visit, there are existing components to support the system such as polyethene tank (2000 gallon), gutter system and downpipe at the mosque. To make sure it is a complete rainwater catchment and conveyance, first flush pipe, valve, overflow pipe and filtration system needs to be installed too. Before the construction begins at the project site, building design, building function and location of the water tank needs to be studied. The mosque has a roof pitch design with 120 meter square area and five water tanks were located in the mosque storage area. It is vital for a mosque to collect clean water, especially if it is going to be used for wudu (Islamic act of washing part of the body using water before one prays). The mosque also surrounded by an ample open space. To increase the water capacity, an additional rainwater harvesting structure can be suggested to be built around the mosque. Space function, suitable type of rainwater harvesting and maintenance checklist needs to be prepared to ensure the effectiveness of the proposed idea. According to site visit, there are existing components to support the system such as polyethylene tank (2000 gallon), gutter system and down pipe at the mosque. To make sure it is a complete rainwater catchment and conveyance, first flush pipe, valve, overflow pipe and filtration system needs to be installed too. Before the construction begin at the project site, building design, building function and location of water tank needs to be studied. The mosque has a roof pitch design with 120 meter square area and five water tanks were located in the mosque storage area. It is important for a mosque to collect a clean water especially if it is going to be used for wudu (Islamic act of washing part of the body using water before one prays). The mosque also surrounded by large open space. To increase the water capacity, an additional rainwater harvesting structure can be suggested to be built around the mosque. Space function, suitable type of rainwater harvesting and maintenance check list needs to be prepared to ensure the effectiveness of the proposed idea.

\subsubsection{Semi Structured Interview Session}

The research sample of the interview session is among ten villagers who joined the site observation. A semi-structured interview question was conducted to measure villagers concerning the water issue, their knowledge on water harvesting and technical skill to construct and maintain the system. From the interview session, the majority of the villagers reported that they were worried about the water shortening issue. They also suggested the local authority to consider extra trips by water truck to supply the water. Some villagers said the rainwater tank could only supply two to three days of water use for each household. These situations become worse during the dry season. There is also some limitation of knowledge to install the rainwater system as it requires detail construction and someone who well experienced to explain and teach them on how to monitor the system.

\subsubsection{Questionnaire Survey}

In the present study, the rainwater system is still under construction at the project site. After the system has been constructed, the research will continue to the structured questionnaire survey. The questionnaire survey will use both type of data collection which are quantitative and qualitative for data collection and analysis. The questionnaire will measure the level of public awareness, the effectiveness of knowledge transfer and, technical and financial feasibility. A set of the questionnaire will be distributed and analyzed by the researcher. Several samples will be based on villagers who will participate in the rainwater harvesting project. To identify the effectiveness of Rainwater Harvesting Project, the questionnaire design will adopt The Convention's Communication, Education and Public Awareness (CEPA) programme that established under the International Union for Conservation of Nature (IUCN). CEPA is a suitable tool and process that can bring changes to the community understanding of the outdoor environment and human needs. The reliability and suitability of the questionnaire will be tested too. The questionnaire will be divided into three sections, respectively. Section A on User's Demographic Background, Section B is on User Communication and Understanding on the Technical Skills, Effectiveness of Knowledge Transfer and Awareness on the Important to Recycle the Rainwater using Proper System. Section C is an open-ended question on the user's financial feasibility for long term implementation of the rainwater harvesting system. The questionnaire will be analyzed by using the IBM Statistical Package for Social Sciences Version 20 (SPSS). The type of statistical analysis will be the frequency distribution, cross-tabulation and chi-square. 


\subsection{Result and Discussion}

This project applies an appropriate process of work starting from the literature review, site observation, site interview, installation of rainwater harvesting at the potential site and questionnaire survey to measure the effectiveness of the system for the users. It also attempts to transfer knowledge between experts and community on the technical installation of the rainwater harvesting system and guide the community to construct their system successfully. It is hoped that the applied technique will solve their problem and increase their understanding of the rainwater harvesting system.

\subsection{Conclusion}

RWH is not new in Malaysia, successful studies and existing projects of the RWH system can be found as indicators for Malaysia to move further. Several strategies can be improvised along with this mission, such as for the government to provide rebates, incentives and tax exemptions for the building owners who installed the RWH. Furthermore, building design in Malaysia should be encouraged to implement RWH facilities to encourage rainwater harvesting practice in the construction industries. For the reported case study, conducting a detail site survey at the project site such as site criteria, factors that contribute to site problem, interview with the end-users is essential for the early part of the research. Finally, a successful RWH system will see its full usage through the sharing of information with regards to the method of installation and maintenance work carried out among the community will ensure the long term benefits of the system.

\section{Acknowledgements}

The author gratefully acknowledges the researchers who embarked their studies on Rainwater Harvesting and financial assistance provided by Universiti Malaysia Sarawak to carry out this research paper.

\section{References}

Belmeziti, A., Coutard, O., de Gouvello, B. (2014). How much drinking water can be saved by using rainwater harvesting on a large urban area? Journal of Water Science Technology, Volume 70 (1782-1788).

Campisano, A., Butler, D., Ward. S., Burns, M.J., Friedler, E. (2017). Urban Rainwater Harvesting System: Research, Implementation and Future Perspectives. Journal of Water Research, Volume 115 (195-209).

Che-Ani, A., Shaari, N., Sairi, A., Zain, M., Tahir, M. (2009). Rainwater Harvesting as an Alternative Water Supply in the Future. European Journal of Scientific Research, Volume 34 (132-140).

Che Ngah, M.S.Y., Othman, Z., Hasim, M., Nayan, N., Saleh., Y. (2014). Application of Rainwater Harvesting System for Sustainable Water Resources: Case Study of Tanjung Malim, Malaysia. International Conference on Green Infrastructure and Sustainable Societies. Paper Proceeding (25-31).

Chiu, Y.-R., Liaw, C.-H., Chen, L.-C. (2009). Optimizing Rainwater Harvesting Systems as an Innovative Approach to Saving Energy in Hilly Communities. Journal of Renewable Energy, Volume 34 (492-498).

Department of Irrigation and Drainage. Rainwater Harvesting Guidebook (2009), Retrieved on 30 Mac 2020 from https://water.gov.my/index.php/pages/view/585. Fung, K.F., Huang, Y.F., Koo, C.H. (2020). Seasonal Hydrological Drought Indicator for Tropical Drought Identification. International Journal of Environmental Science and Development, Volume 11 (99-105).

Halim, Z.A,, Din, A.T,, Tokit, E.M., Rosli, M.A.M. (2018). Development of Rainwater Harvesting System for Sekolah Menengah Kebangsaan Iskandar Syah Melaka. International Conference on Sustainable Energy and Green Technology. Volume 1 (234-231).

Hashim, H., Hudzori, A., Yusop, Z., Ho, W.S. (2013). Simulation Based Programming for Optimization Large-Scale Rainwater Harvesting System: Malaysia case study. Journal of Resource Conservation Recycle, Volume 80 (1-9).

https://suarasarawak.my/2020/03/15/projek-sulam-tingkat-nilai-kemanusiaan/

http://www.met.gov.my/data/climate/tinjauancuacajangkapanjang.pdf

Integrated Resource Water Management (IRWM) (2020), 10 Pillars for Sustainable Water Resource Management Plan. Retrieved on 30 Mac 2020 from https://aseaniwrm.water.gov.my/iwrm-in-malaysia/

Kuok, K.K and Chiu, P.C (2020). Optimal Rainwater Harvesting Tank Sizing for Different Types of Residential Houses: Pilot Study in Kuching, Sarawak. Journal of Engineering Science and Technology. Volume 15 (541-544).

Jimenez, A., Saika, P., Gine, R. (2020). Unpacking Water Governance: A Framework for Practitioners. Journal of Water. Volume 12 (827-238).

Law, B.K.E and Bustami, R.A (2013). A Study on Potential of Rainwater Harvesting System in SJK Chung Hwa No. 2, Kuching. UNIMAS e- Journal of Civil Engineering, Volume 4 (28-33)

Lee, K.E., Mokhtar, M., Mohd Hanafiah, M., Abdul Halim, A and Badusah, J. (2016). Rainwater Harvesting as an Alternative Water Resources in Malaysia. Journal of Cleaner Production, Volume 126 (218-222). 
Md Lani, N.H., Yusop, Z., Syafiuddin. A. (2018). Review of Rainwater Harvesting in Malaysia: Prospects and Challenges. Journal of Water Research, Volume 10 (506527).

Ministry of Natural Resources and Environment Malaysia. Water Resource Policy 2012 (2012). Retrieved on 23 Mac 2020 from http://www.kats.gov.my/ms my/pustakamedia/Penerbitan/Dasar2Sumber Air Negara.pdf

Mohamad, N.A. (2020). Research on Rainwater Harvesting for Drinking Water, Project Presentation at National Colloquium on Research and Water Development 2020 Malaysia.

Mohammad, M.F., Musa, M.F., Yusof, M.R. (2014). The Awareness Among Developers on Rainwater Harvesting System (RWHS). International Colloquium on Science and Technology. Volume 1 (97-102).

Nasif, M.S., Roslan, R. (2016). Effect of Varying Roof Run Off Coefficient Values and Tank Size of Rainwater Harvesting System Water Saving in Malaysia. Journal of Engineering and Applied Science. Volume 11 (12934-12941).

NAHRIM Strategic Plan (2016-2020). National Hydraulic Research Institute of Malaysia. Retrieved on 30 Mac 2020 from http://www.nahrim.gov.my/en/publications/listofpublications.html.

Saidin, E. (2009). A study of Rainwater Harvesting System Installations at Three Residential Houses in Malaysia. Perunding Ikatan, Malaysia. Retrieved on 14 May 2020 from http://citeseerx.ist.psu.edu/viewdoc/summary?doi=10.1.1.731.2137

Shaari, N., Che-Ani, A.I., Nasir, N., Tawil, N.M.; Jamil, M. (2009). Implementation of Rainwater Harvesting in Sandakan: Evolution of Sustainable Architecture in Malaysia Proceedings of the Regional Engineering. Postgraduate Conference, Kuantan, Malaysia, 20-21 October 2009.

The Star News (2017). Rainwater Harvesting Gaining Traction. Retrieved on 23 Mac 2020 from https://www.thestar.com.my/metro/metro-news/2017/10/23/turning-to-theheavens-for-waterl

Zakaria, S. (2019). Transforming the Water Sector: Working in an Integrated Manner. Kick off Conference 12th Malaysia Plan, Ministry of Economic Affairs, Malaysia. 